\title{
Analysis of absolute nuclear DNA content reveals a small genome and intra-specific variation in Cashew (Anacardium occidentale L.), Anacardiaceae
}

\author{
By O. M. AliYu ${ }^{1), *)}$
}

(Received $9^{\text {th }}$ January 2015)

\begin{abstract}
There are scanty data on genome size of Anacardiaceae, and none has been reported for cashew, Anacardium occidentale till date. This study aimed at determining the absolute nuclear DNA content (genome size) that could facilitate research into bio-systematics, genomics and genetic improvement of this important tropical tree crop species. Here, isolated nuclei of preparations from 43 cashew accessions selected across five growing regions were flow cytometrically analyzed for genome size determination using Solanum lycopersicum var. Stupicke with a genome size of $1.96 \mathrm{pg} / 2 \mathrm{C}$ as an internal reference standard.

Mean genome size was significantly different $(P<0.01)$ across the 43 cashew accessions suggesting intra-specific variation (about 3.6\% coefficient of variation) for absolute nuclear DNA content in this species, but with no evidence of endopolyploidy or endoreduplication. Flow cytometric analysis data presented here showed that absolute genome size of cashew is about 0.857 $\mathrm{pg} / 2 \mathrm{C}(419 \mathrm{Mb} / 1 \mathrm{C})$. However, there was a slight gradual increment in genome size from south to north gradient across sampled populations. The data also showed significant correlation $(r=0.368, P<0.01)$ between nuclear DNA content (genome size) and phenotypic trait, nut weight. The results obtained here confirmed relatively small genome size in this tree species, almost twice genome size of diploid Arabidopsis thaliana but slightly lower than mango, Mangifera indica, a close relative in Anacardiaceae. Similarity in genome size between Mangifera indica and Anacardium occidentale could be a further proof of genetic relatedness between these two important species of Anacardiaceae.
\end{abstract}

Key words: Anacardium occidentale; Cashew; Correlation analysis; Genome size; Nuclear DNA content; Nut weight.

\section{Introduction}

Cashew, Anacardium occidentale is an important tropical nut tree that belongs to family Anacardiaceae. The family comprises about 82 genera and over 700 species (PELL, 2004) and is characterized by cultivated edible fruits and seeds. Examples are mangos, pistachios, and cashews. Cashew plant has been described as a polymorphic species with chromosome numbers ranging

\footnotetext{
1) Department of Cytogenetics and Genome Analysis, Institute of Plant Genetics and Crop Plant Research (IPK), Correnstrasse 3, 06466 Gatersleben, Germany.

E-Mail: walealiyu@mail.com, aliyu@ipk-gatersleben.de

*) Current Address of author: Olawe MAshood Aliyu. Department of Crop Production, Kwara State University, Malete, PMB 1530, Ilorin, Nigeria. E-Mail. olawale.aliyu@kwasu.edu.ng
}

between $2 n=24$, and $2 n=42$ (DECKERs et al., 2001). This tropical nut tree is native to the Brazilian Amazonia forest, which is also the primary centre of its diversity (Mitchell and MoRI, 1987). Although it has become naturalized in tropical worlds (MITCHELL and MoRI, 1987; RICKSON and RICKSON, 1998; BHASKARA-RAO and SWAMY, 2005), recent data on cashew nut fossils identified in 47million year old lake sediments in Germany have shown evidence of its earlier distribution in Europe (MANCHESTER et al., 2007). Cashew produces nuts from which the edible and highly nutritive kernel is extracted and roasted as dessert. High grade roasted kernels are major export to industrialized nations and source of foreign exchange earnings for third-world producing nations (BHASKARA-RAO and SWAMY, 2005). In addition to the kernel extracted from drupaceous cashew nut, the attached pseudo-fruit (apple) could be either consumed fresh or processed into juice and assorted drinks (PARAMShIVAPPA et al., 2001). Generally, there had being increased contribution of cashew industry to the national economic development in a number of developing countries in Asia, Africa, and South and Central America in the recent time, especially in the rural areas (MARTIN et al., 1997; ALIYU and HAMmED, 2008). Hence, there would be need for more research into the crop species.

In spite of importance of genome size in speciation and diversification of angiosperms (GREGORY, 2005; BENNETT and LEITCH, 2011), it remains poorly studied in woody angiosperms (CHEN et al., 2014). Few genome size data available on trees were predominantly published on temperate species. In other words, little is known till date about genome size of many tropical tree species. Recent search (10 November, 2014) of the plant genome size database (BENNETT and LEITCH, 2012; http://data.kew.org/cvalues), revealed that nuclear DNA contents for only six species across 4 genera in the family Anacardiaceae were so far reported. They are Cotinus coggygria Scop. (ZoNneveld et al., 2005); Lannea coromandelica (Houtt.) Merr. (OHRI et al., 2004); Lannea grandis (Dennst.) Engl. (OHRI et al., 2004); Mangifera indica L. (ARumugathan and Earle, 1991); Pistacia lenticus L. (SIlJAK-YAKOVLEV et al., 2010) and Pistacia terebinthus L. (HoRJALES et al., 2003; SilJAK-YAKOvLEV et al., 2010). Till date, there has not being any report of genome size (absolute nuclear DNA content) in cashew, Anacardium occidentale, in spite of increasing research into its breeding and genetic improvement. To this end, here 43 cashew accessions from diverse ecologies (growing areas) were analyzed to determine the absolute nuclear DNA content for this plant species, using a flow cytometric procedure described by DoLEŽEL et al. (2007). 


\section{Materials and Method}

\section{Plant System}

Leaf tissue samples for analysis were collected from seedlings raised from forty-three (43) cashew accessions collected across 5 major growing areas in Nigeria (Table 1). Five seedling plants were raised per accession in a 5 litres plastic-pot containing top soil and compost. The young plants were nurtured under green house condi- tions with average temperature of $24^{\circ} \mathrm{C}$ and 16 -hour photoperiod at the greenhouse facilities of the Institute for Plant Genetics and Crop Research (IPK), Gatersleben, Germany. Leaf samples for genome size analysis were collected 4 weeks after germination to reduce stoichiometric error from high metabolic (secondary) and phenolic compounds commonly associated with very young leaves (LOUREIRO et al., 2006; DOLEŽEL et al., 2007). Samples were collected from three individuals

Table 1. - Geographical/Climatic data and locations of 43 cashew accessions.

\begin{tabular}{|c|c|c|c|c|c|c|c|}
\hline Location & $\begin{array}{l}\text { No. of } \\
\text { accessions } \\
\text { collected }\end{array}$ & $\begin{array}{l}\text { Accession } \\
\text { Code }\end{array}$ & Longitude & Latitude & $\begin{array}{l}\text { Altitude } \\
\text { (asl) }\end{array}$ & $\begin{array}{l}\text { Annual } \\
\text { Rainfall } \\
\text { (mon) }\end{array}$ & $\begin{array}{l}\text { Annual } \\
\text { Temperaturc } \\
(\mathrm{C})\end{array}$ \\
\hline Offa $(\mathrm{FFA})$ & 4 & $\triangle \mathrm{AD}$ & $4.72^{\circ} \mathrm{E}$ & $8.15 \mathrm{X}$ & $436 \mathrm{~m}$ & 955.5 & 30 \\
\hline Oro $(O R O)$ & 9 & $\mathrm{OB}, \mathrm{OS}$ & $4.91^{\circ 1} \mathrm{E}$ & $8.22^{11} \mathrm{X}$ & $448 \mathrm{~m}$ & 913.5 & 30 \\
\hline $\begin{array}{l}\text { CRLA Ibadan } \\
\text { (CR-lB) }\end{array}$ & 13 & $\begin{array}{l}\mathrm{CC}, \mathrm{CE}, \mathrm{CJ}, \\
\mathrm{CM}, \mathrm{Cl}^{\prime}\end{array}$ & $3.90^{\circ} \mathrm{E}$ & $7.35 \times$ & $239 \mathrm{~m}$ & 1250 & 25 \\
\hline $\begin{array}{l}\text { University, } \\
\text { Abeokuta } \\
\text { (UNA) }\end{array}$ & 10 & $U B$ & $3.35^{\circ} \mathrm{E}$ & $7.15 \times$ & $67 \mathrm{~m}$ & 1181.3 & 25 \\
\hline Ochaja (OCII) & 7 & $O C$ & $7.16^{\prime \prime} \mathrm{E}$ & $7.51^{\circ}$ & 420 & 1115 & 28 \\
\hline
\end{tabular}

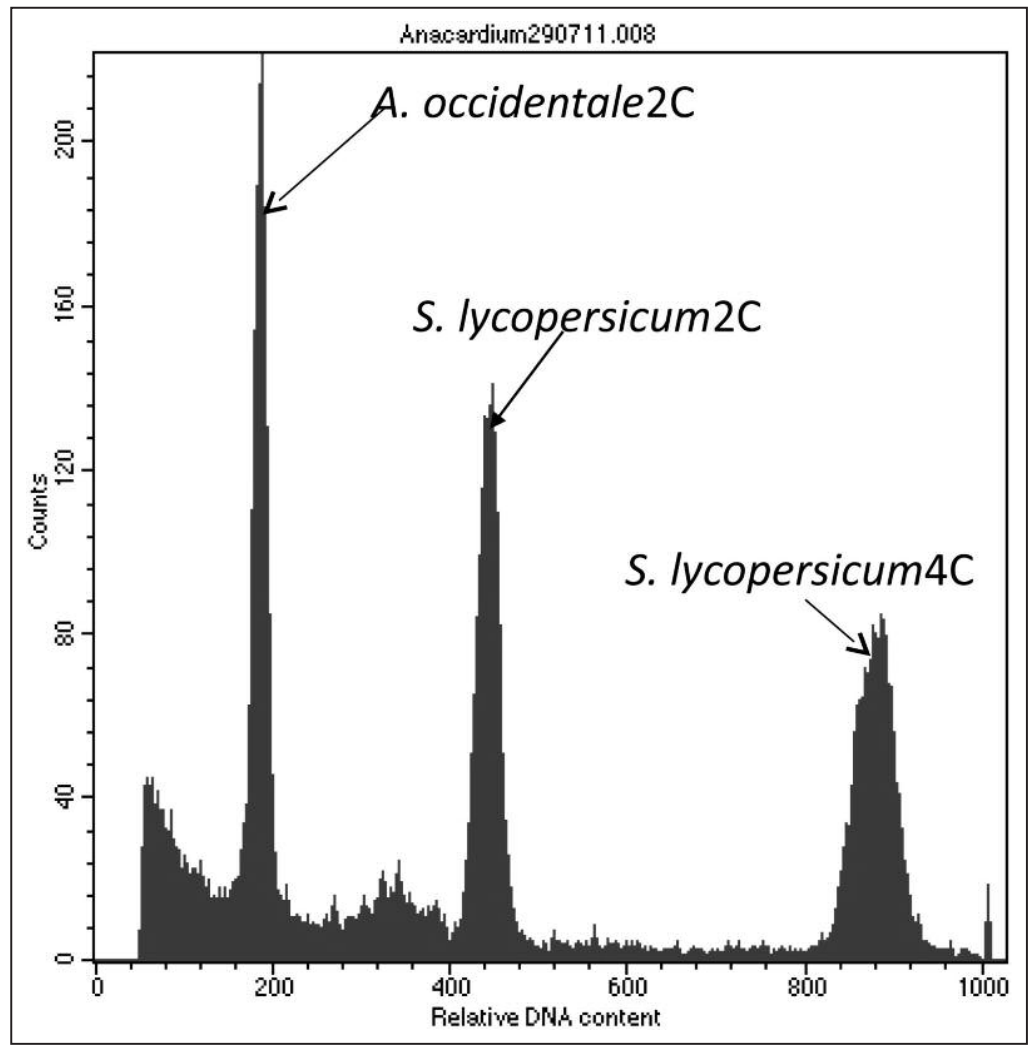

Figure 1. - A representative histogram of fluorescence intensity of isolated DNA nuclei from leaf sample of UB-7 accession of Anacardium occidentale and internal reference standard Solanum lycopersicum, var. Stupicke with a genome size of $1.96 \mathrm{pg} / 2 \mathrm{C}$; (Dolezel et al., 1992). 
Table 2. - Variance analysis of Genome size and nut weight of 43 cashew accessions.

\begin{tabular}{llllll}
\hline & $\begin{array}{l}\text { Source of } \\
\text { variation }\end{array}$ & $\begin{array}{l}\text { Degree of } \\
\text { freedom }\end{array}$ & Mean square & $\mathrm{F}$ & $\mathrm{P}$ \\
\hline Genome sire & Replication & 4 & 0.000039 & 0.5587 & $.6929 \mathrm{~ns}$ \\
& Accession & 42 & 0.00463 & 66.3224 & $.0000 * * *$ \\
& Residual & 168 & 0.000698 & & \\
Nut Weight & Replication & 4 & & & $.0887 \mathrm{~ns}$ \\
& Accession & 42 & 1.266575 & 2.055685 & $.0000 * * * *$ \\
& Residual & 168 & 38.39356 & 62.31376 & \\
\hline
\end{tabular}

**** indicates significant difference at $P<0.001$, and ns indicates not significant difference.

per accession for the genome size determination. A total of fifteen determinations were done for each accession and carried out in 5 replicates across different days (DOLEŽEL and BARTOS̆, 2005; LOUREIRO et al., 2006). Leaf samples for the internal reference standard were collected from young tomato (Solanum lycopersicum var. Stupickle) plants raised under the same growing conditions described for the cashew plants.

\section{Genome size analysis}

About $50 \mathrm{mg}$ of young leaf tissue of each plant sample was chopped together with an internal reference standard (leaf tissue of Solanum lycopersicum, var. Stupicke, with a genome size of $1.96 \mathrm{pg} / 2 \mathrm{C}$; DoLEŽEL et al., 1992) in a Petri dish containing $1.0 \mathrm{ml}$ cold nuclei isolation buffer (GALBRAITH et al., 1983) supplemented with DNAse-free RNase $(50 \mu \mathrm{g} / \mathrm{ml})$ and Propidium Iodide (50 $\mu \mathrm{g} / \mathrm{ml})$. The isolation buffer comprises $45 \mathrm{mM}$ $\mathrm{MgCl}_{2} \cdot 6 \mathrm{H}_{2} \mathrm{O}, 30 \mathrm{mM}$ Tri-sodium Citrate, 20 mM 3-Morpholine-1-Propane-Sulfonic acid (MOPS: \#M3183, Sigma-Aldrich, St. Louis, MO, USA), supplemented with $1 \%(\mathrm{w} / \mathrm{v})$ Triton X-100 and 1\% (w/v) Polyvinyl pyrrolidone-(PVP-40) and the buffer was adjusted to $\mathrm{pH} 7.2$. The concentrations of Triton X-100 and PVP-40 are ideal for reducing the effect of phenolic compounds and cellular debris (DolEžEL et al., 2007; CHEN et al., 2014). The nuclear suspension was filtered through a $35 \mu \mathrm{m}$ mesh filter and incubated for at least 20 minutes on ice in the darkness before analysis. The relative fluorescence intensities of isolated nuclei were measured with a FACStar PLUS (BD Biosciences) flow sorter equipped with an argon ion laser INNOVA 90C (Coherent) aligned to 514 $\mathrm{nm}$, and about 5000 nuclei per sample were analyzed using the software CELL Quest 3.3 (BD Biosciences). Noises from cellular debris were gated off and instrument linearity was routinely checked. A total of fifteen measurements were analyzed per accession in five replicates. However, replicate measurements were carried out on different days (see DoLEŽEL and BARTOS̆, 2005). Absolute genome size was computed from the histogram
G0/G1 peaks, (with coefficient of variations $(\mathrm{CVs})$ less than $4 \%$ ) for both cashew sample (Annacardium occidentale) and internal reference standard (Solanum lycopersicum) (Figure 1). The genome size was expressed in both pg and base-pair (bp) using a factor of $1 \mathrm{pg}=978$ Mb (DOLEŽEL et al., 2003).

\section{Nut weight measurements}

To study the relationship between absolute nuclear DNA content and a plant phenotypic trait, individual nut weight of at least 100 nuts each across the 43 cashew accessions was measured with laboratory weighing balance after air-drying to $9 \%$ moisture content. Data on nut weight were recorded for 3 years to minimize bias due to environmental effects (see ALIYU et al., 2014).

\section{Statistical Analysis}

Nuclear DNA content for each sample was computed using equation by DolEžEL et al. (2007). The measurements were summarized and statistically tested using one-tailed ANOVA (Table 2) and mean values were separated using Duncan's multiple range test (DMRT) at $P<0.05$. Variance analysis was computed at both, accession and population (location) levels for genome size and nut weight data. Pearson correlation analysis was also carried out on genome size and nut weight data to determine relationship between absolute nuclear DNA content and nut weight in cashew.

\section{Results}

\section{Genome size variation among cashew accessions}

Repeated measurements across the 43 cashew accessions were highly reproducible as variation due to replication was statistically not significant (Table 2). The standard deviation of genome size ranged between 0.003 pg for 3 accessions (OB-Y3, AD-R1 and OC-IY) and $0.016 \mathrm{pg}$ for CJ-18. These standard deviation values cor- 
Table 3. - Variation in mean genome size (pg/2C, pg/1C, $\mathrm{Mb} / 2 \mathrm{C}$ and $\mathrm{Mb} / 1 \mathrm{C})$ across 43 cashew accessions.

\begin{tabular}{|c|c|c|c|c|c|}
\hline $\begin{array}{l}\text { Accession } \\
\text { ID }\end{array}$ & $\begin{array}{l}\text { Mecan } \\
p g / 2 C\end{array}$ & $\begin{array}{l}\text { Siandard } \\
\text { Deviation }\end{array}$ & $\begin{array}{l}\text { Mean } \\
p g / / C\end{array}$ & $\begin{array}{l}\text { Mean } \\
\mathrm{Mb} / 2 \mathrm{C}\end{array}$ & $\begin{array}{l}\text { Mean } \\
\mathrm{Mb} / \mathrm{C}\end{array}$ \\
\hline$\Lambda D-Y 1$ & 0.899 & 0.008 & 0.450 & 879 & 440 \\
\hline $\mathrm{CJ}-3$ & 0.898 & 0.004 & 0.449 & 878 & 439 \\
\hline$\Lambda D-R 2$ & 0.893 & 0.007 & 0.447 & 874 & 437 \\
\hline $\mathrm{OB}-\mathrm{Y}_{2}$ & 0.891 & 0.006 & 0.446 & 872 & 436 \\
\hline L:B-3 & 0.889 & 0.004 & 0.445 & 870 & 435 \\
\hline$A D-Y 2$ & 0.888 & 0.004 & 0.444 & 868 & 434 \\
\hline OB-RI & 0.887 & 0.007 & 0.443 & 867 & 434 \\
\hline CMA-G & 0.882 & 0.011 & 0.441 & 863 & 431 \\
\hline $\mathrm{CJ}-2$ & 0.880 & 0.008 & 0.440 & 861 & 431 \\
\hline CJ-6 & 0.878 & 0.008 & 0.439 & 859 & 429 \\
\hline $\mathrm{OB}-\mathrm{Y}_{3}$ & 0.878 & 0.003 & 0.439 & 858 & 429 \\
\hline$L B-10$ & 0.877 & 0.010 & 0.439 & 858 & 429 \\
\hline OS-Y 1 & 0.875 & 0.011 & 0.438 & 856 & 428 \\
\hline CJ-18 & 0.874 & 0.016 & 0.437 & 855 & 427 \\
\hline OS-Y2 & 0.874 & 0.007 & 0.437 & 854 & 427 \\
\hline OS-R 1 & 0.872 & 0.006 & 0.436 & 852 & 426 \\
\hline $\mathrm{OB}-\mathrm{Y} 1$ & 0.871 & 0.005 & 0.435 & 852 & 426 \\
\hline$A D-R]$ & 0.870 & 0.003 & 0.435 & 851 & 425 \\
\hline LBB-I & 0.869 & 0.010 & 0.434 & 850 & 425 \\
\hline OC-GO & 0.866 & 0.004 & 0.433 & 847 & 423 \\
\hline $\mathrm{OC}-7 \mathrm{Y}$ & 0.862 & 0.005 & 0.431 & 843 & 422 \\
\hline OS-R2 & 0.859 & 0.004 & 0.430 & 840 & 420 \\
\hline $\mathrm{CMA}-7$ & 0.857 & 0.004 & 0.429 & 838 & 419 \\
\hline $\mathrm{OC}-\mathrm{MY}$ & 0.857 & 0.007 & 0.428 & 838 & 419 \\
\hline $\mathrm{LB}-5$ & 0.855 & 0.009 & 0.428 & 836 & 418 \\
\hline CT-12 & 0.855 & 0.011 & 0.427 & 836 & 418 \\
\hline $\mathrm{LB}-4$ & 0.852 & 0.007 & 0.426 & 833 & 417 \\
\hline L:B-9 & 0.851 & 0.007 & 0.426 & 833 & 416 \\
\hline L'B-6 & 0.844 & 0.009 & 0.422 & 825 & 413 \\
\hline OC-IR & 0.842 & 0.009 & 0.421 & 824 & 412 \\
\hline OC-7R & 0.841 & 0.006 & 0.420 & 822 & 411 \\
\hline L:B-8 & 0.839 & 0.004 & 0.420 & 821 & 410 \\
\hline $\mathrm{OB}-\mathrm{R} 3$ & 0.839 & 0.008 & 0.419 & 820 & 410 \\
\hline $\mathrm{CN}-66$ & 0.837 & 0.010 & 0.419 & 819 & 409 \\
\hline$O C-M R$ & 0.837 & 0.006 & 0.419 & 819 & 409 \\
\hline CE-1 & 0.835 & 0.008 & 0.418 & 817 & 408 \\
\hline L'B-7 & 0.833 & 0.008 & 0.417 & 815 & 407 \\
\hline CME-IJ & 0.830 & 0.009 & 0.415 & 812 & 406 \\
\hline OC-IY & 0.829 & 0.003 & 0.415 & 811 & 406 \\
\hline $\mathrm{L} B \mathrm{~B}-2$ & 0.810 & 0.004 & 0.405 & 793 & 396 \\
\hline CMA-4 & 0.803 & 0.007 & 0.402 & 785 & 393 \\
\hline$C M \wedge-5$ & 0.797 & 0.004 & 0.398 & 779 & 390 \\
\hline $\mathrm{CC}-11$ & 0.743 & 0.006 & 0.372 & 727 & 363 \\
\hline Total Mean & 0.857 & 0.013 & 0.428 & 837 & 419 \\
\hline
\end{tabular}

respond to about $0.24 \%, 0.34 \%, 0.35 \%, 0.36 \%$ and $1.83 \%$ of the respective mean genome sizes of the 4 cashew accessions. However, variance analysis of genome size across the 43 accessions was statistically different at $P<0.01$, an indication of genome size varia- tion among these cashew accessions (Tables 2, 3). Individual mean genome size across the cashew accessions ranged between $0.743 \mathrm{pg} / 2 \mathrm{C}$ for $\mathrm{CC}-11$ and $0.899 \mathrm{pg} / 2 \mathrm{C}$ for $\mathrm{AD}-\mathrm{Y} 1$ (i.e. about $20 \%$ fold) (see Table 3). And total coefficient of variation (CV\%) of the genome size was 
about $3.62 \%(\mathrm{sd} / \overline{\mathrm{u}} \times 100)$. Where $\mathrm{sd}$ is the standard deviation and $\bar{u}$ is the total mean for genome size. A total mean genome size of $0.857 \mathrm{pg}$ (i.e. $837 \mathrm{Mb}$ ) for $2 \mathrm{C}$ genome and/or $0.428 \mathrm{pg}(419 \mathrm{Mb})$ for $1 \mathrm{C}$ genome was recorded for these 43 cashew accessions (Table 3). And based on data presented here, intraspecific genome size variation between the smallest and largest $1 \mathrm{C}$ genomes of cashew is about $77 \mathrm{Mb}$.

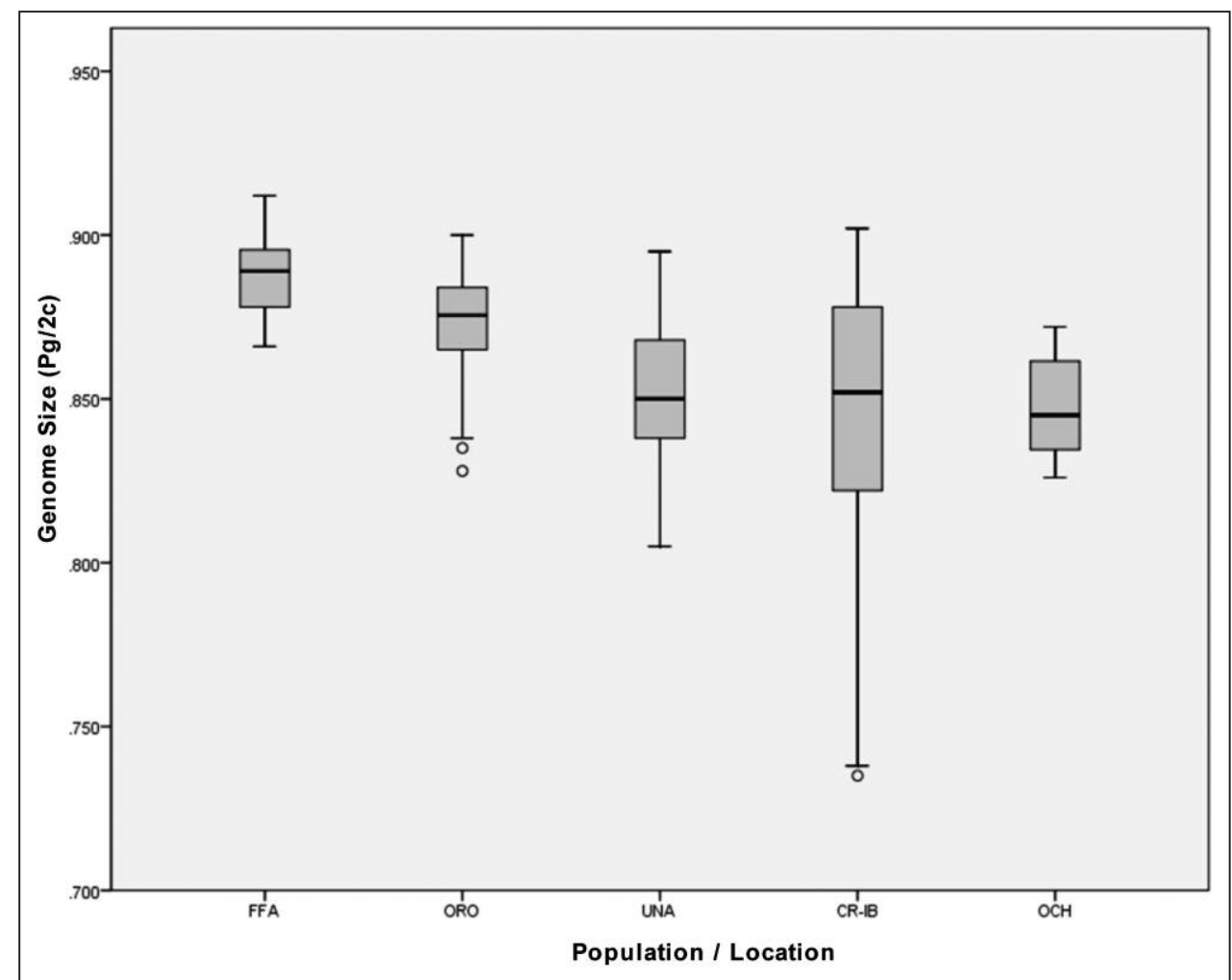

Figure 2. - Distribution of genome size across 5 locations, Offa (FFA), Oro, University of Agriculture Abeokuta (UNA), Cocoa Research Institute of Nigeria Ibadan (CR-IB) and Ochaja $(\mathrm{OCH})$ where 43 cashew accessions were collected.

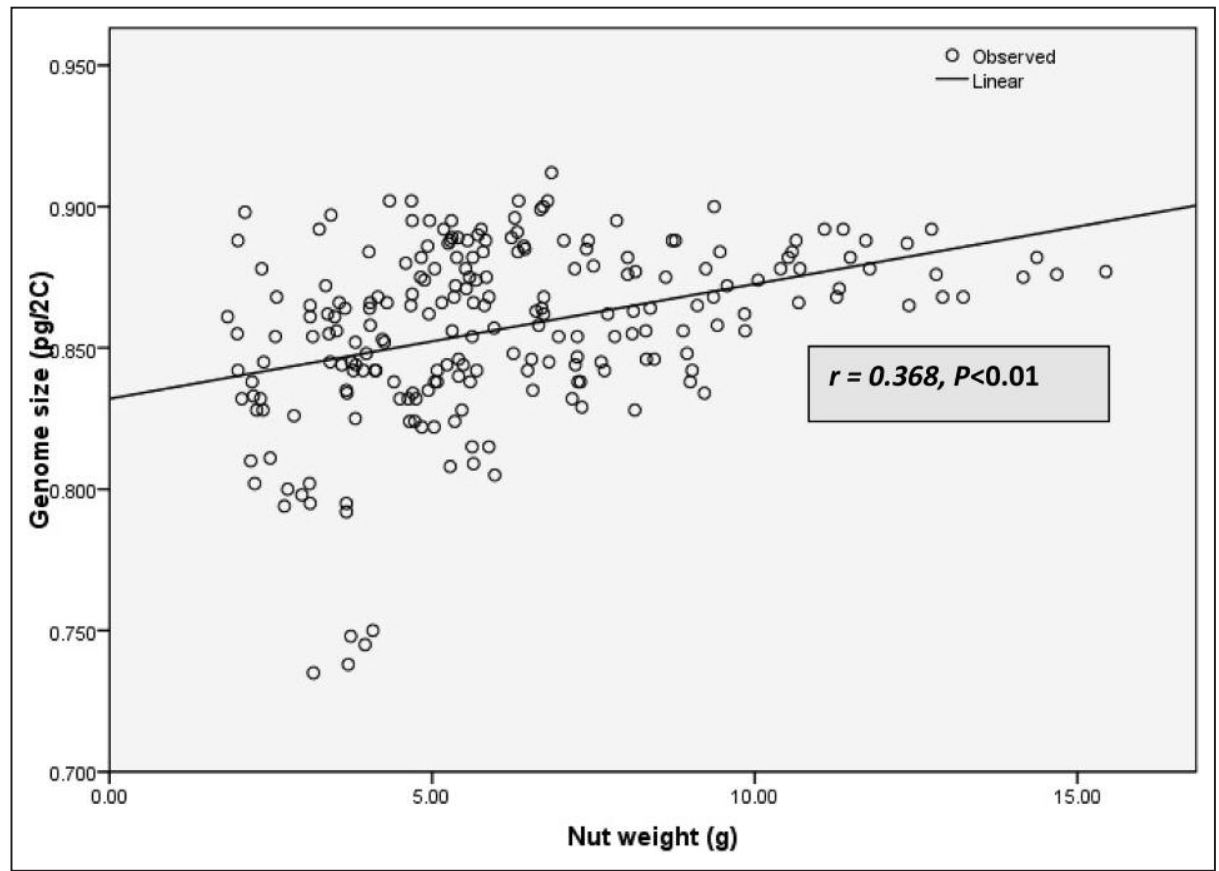

Figure 3. - Pearson correlation analysis showing relationship between nut weight (g) and absolute nuclear DNA content (pg/2C) of cashew. 


\section{Genome size variation across locations}

Mean genome sizes across accessions from different locations showed slight variation from lower elevation (south) to higher elevation (north) (Figure 2). The largest and smallest genome sizes of $0.888 \mathrm{pg} / 2 \mathrm{C}$ and $0.844 \mathrm{pg} / 2 \mathrm{C}$ were recorded for accessions collected from Offa (north) and CRIN, Ibadan (south), respectively (Figure 2). Thirteen (13) accessions from CRIN, Ibadan (southern elevation) exhibited the highest variation in genome size $(0.735-0.902 \mathrm{pg} / 2 \mathrm{C})$ and while least variation were recorded for cashew accessions sampled from Offa and Ochaja (northern elevation) (Figure 2). In spite of these variations, average genome sizes of cashew samples from Ochaja (north) and CRIN, Ibadan (south) were found to be comparatively close, $0.844 \mathrm{pg} / 2 \mathrm{C}$ and $0.848 \mathrm{pg} / 2 \mathrm{C}$, respectively.

\section{Correlation between absolute nuclear DNA content and nut weight in cashew}

Analysis of variance of 3-year nut weight data showed highly significant $(P<0.01)$ variation of nut weight among the 43 cashew accessions sampled in this study (Table 2), with average nut weight ranging between $2.14 \mathrm{~g}$ (smallest) and 13.81g (largest) for OC-IR and OBY3 cashews, respectively (data not shown). Pearson correlation analysis of absolute genome size and nut weight data showed highly significant correlation between variation in absolute nuclear DNA content and nut weight in these cashew plants (Figure $3, r=0.368, P<0.01$ ).

\section{Discussion}

The importance of genome size for genetic improvement in crop plant species cannot be overemphasized. However, such important data are rare in tropical tree crop species like cashew; hence this study was carried out to determine absolute genome size in this crop plant using a flow cytometric procedure to analyzed 43 samples collected from 5 different localities in Nigeria (Table 1). Importantly, all flow cytometric histogram profiles (about 700) analyzed produced a single G0/G1 2C peak for cashew, Anacardium occidentale (see Figure 1), a phenomenon suggesting lack of endopolyploidy (endoreduplication) in cashew genome. This observation is in contrast to tomato, Solanum lycopersicum (internal reference standard plant) with high frequency of endopolyploid peaks (Figure 1 this data, CHEvalier et al., 2011). This observation probably suggests that endoreduplication do not play significant role in growth and development of cashew plants. Till date, the issue of genome ploidy level in some species within family Anacardiaceae still remains a conundrum. For example, Mango, Mangifera indica L. a closely related genus in Anacardiaceae has been reported to be an allopolyploid (MuKHEREJEE, 1950) with 40 chromosomes and a tetraploid (ARUMUGANTHAN and EARLE, 1991). But recent molecular studies reported Mangifera indica to be a diploid species (DUVAL et al., 2005; VIRUEL et al., 2005; Schnell et al., 2006). Similar to Mango, chromosome counts had shown that cashew has 42 somatic chromosomes (AlIYU and AwOPETU, 2007). And microsatellite markers data of about 450 cashew accessions (including materials used in this study) indicates diploid ploidy for cashew (unpublished data). While the ploidy status is yet to be conclusively resolved, the consistent single histogram peaks recorded for cashew samples across all flow cytometric genome size measurements indicates a stable ploidy for this crop plant species. Similar trend was reported on mango (ARUMUGANTHAN and EARLE, 1991).

About 0.20-fold difference in individual mean genome size $(0.743-0.899 \mathrm{pg} / 2 \mathrm{C}$, Table 3$)$ recorded for the 43 cashew accessions studied here provides evidence of intraspecific (C-value) genome size variation in cashew plant. Although, GREILHUBER (1998; 2005) had remarked that many intraspecific $\mathrm{C}$-value variations could be linked to methodological and technical errors, the author however suggested that such errors could be mitigated through replication and measurement across different days. Data presented here were replicate measurements carried out on different days (DOLEŽEL and BARTOŠ, 2005), and with higher replications (NOIROT et al., 2003; Schmuths et al., 2004). In the light of this, intraspecific variation (about $3.6 \%$ coefficient of variation across the 43 samples) recorded here could possibly be attributed to chromosome polymorphism and/or spontaneous aberration (GALBRAITH et al., 1991; GREILHUBER, 1998). Furthermore, analysis of variance of the genome size data presented here showed no significant variation between measurements within and between days. Slight intraspecific variation in genome size observed here is similar to slight intraspecific variation reported in some tropical woody trees (see CHEN et al., 2014). Data presented here showed that cashew has a genome size of $0.857 \mathrm{pg}$ and $837 \mathrm{Mb}$ for $2 \mathrm{C}$ genome and accordingly falls within a class of plants with small genomes. SoLTis et al., (2003) classified plants with genome size of $\leq 1.4 \mathrm{pg} / 2 \mathrm{C}$ to be very small genome. Cashew genome size reported here could not be compared with previous data as none could be found for this plant species. However, comparing it to other plant species, cashew genome size recorded in this study is twice that of Arabidopsis thaliana (DoležEl et al., 1998; Schmuths et al., 2004), five times smaller than corn's genome (DOLEŽEL et al., 1998; JoHnston et al., 1999), and less than half of tomatoes (DoLEŽEL et al., 1992). Importantly, $0.428 \mathrm{pg} / 1 \mathrm{C}$ recorded for cashew here was comparatively closer to $0.45 \mathrm{pg} / 1 \mathrm{C}$ reported in mango, Mangifera indica (ARUMUGANATHAN and EARLE, 1991), a member of the same Anacardiaceae family. The absence of endoreduplication and characteristic smaller genome obtained in this cashew data further support previous hypothesis of smaller genome size and rare polyploidization in woody angiosperms (see CHEN et al., 2014). Furthermore, similarities in somatic chromosome number and genome size between mango, Mangifera indica (ARUMUGANATHAN and EARLE, 1991) and cashew, Anacardium occidentale (ALIYU and Awopetu, 2007; and data being reported here) are more evidences of genetic relatedness of these two Anacardiaceae species. Recent molecular data also showed that these two plant species clustered together in the same clade and diverged about 50 million years ago (see XIE et al., 2014). 
Correlations between intra-specific variation in genome size and environmental gradients or growth conditions have been reported in Coffea (NoIRo et al., 2003, Schmuths et al., 2004). With exception of cashews collected from Ochaja (higher elevation), the results showed a slight gradual increment in genome size of plants selected from lower elevation, south (CRIN Ibadan, and University of Abeokuta) to higher elevation, north (Offa and Oro) gradients (Table 3 and Figure 2). Cocoa Research Institute of Nigeria, Ibadan has a Research Station for conservation of cashew germplasm in Ochaja and there is a high probability that replicates must have been selected from these two (Ibadan and Ochaja) locations and, thus, similarity obtained in genome sizes of cashew plants from these two locations (Table 3 and Figure 2). BENNET et al. (2003) were of the opinion that larger centromeric regions of chromosomes could account for increased genome size of accessions within a species. Further studies with more samples across broader locations would help to validate this preliminary observation in future. Genome plasticity for plant adaptation is a well documented phenomenon in plant species (BENNETZEN and KELLOGG, 1997; BENNETZEN et al., 2005; LEITCH and LEITCH, 2008). Wide variation in climatic variables across geographical gradients could lead to genome obesity/or streamlining, thus, slight change in genome size across gradients.

Relationships between amount of nuclear DNA contents and some plant phenotypic traits (pollen size, stomata size, leaf size and seed size) have been reported in angiosperms (CHUNG et al., 1998; BEAULIEU et al., 2007; KNIGHT et al., 2010). Data presented here indicated significant correlation between nut weight and genome size in cashew. Cell and organ size in plants are also known to be correlated with DNA content (see Strasburger et al., 1991; as quoted by Schmuths et al., 2004). Increased genome size in plants has been linked to increased cell size (CAVALIER-SMITH, 2005; GREGORY, 2005) and increased demand for energy to build extra DNA and large cells (LEITCH and BenNETT, 2004; CAVALIER-SMITH, 2005). Cashew plants raised from large nuts are characterized by large surface leaf area and large food reserves (HAMMED et al., 2014). Correlation between nut size and vigorous growth form in the early stage of cashew development has been reported in these germplasm materials (HAMMED and ADEYEMI, 2005). Further studies should be carried on this intraspecific variation to understand possible role of increased genome across gradient for cashew adaptation.

In conclusion, flow cytometric analysis of 43 cashew samples determined in this study showed that cashew, Anacardium occidentale has a genome size of $0.428 \mathrm{pg}$ and $419 \mathrm{Mb} / 1 \mathrm{C}$. This result would be useful for further genome research in this important tropical tree species.

\section{Acknowledgement}

The author thanks Dr. S. O. OGunwolu, of Cocoa Research Institute of Nigeria, Ibadan, Nigeria and Dr. L. A. HAMmED, of Federal University of Agriculture, Abeokuta, Nigeria for plant materials. Technical assistance of Dr. JoERG Fucus, Department of Cytogenetics,
Institute for Plant genetics and Crop research, IPK, Gatersleben, Germany for flow cytometric measurements is appreciated. Dr. JAROSLAV DolezEL of Institute of Experimental Botany, Czech Republic is appreciated for internal reference standard.

\section{References}

Aliyu, O. M. and J. A. Awopetu (2007): Chromosome studies in cashew (Anacardium occidentale L.). African Journal of Biotechnology, 6 (2): 131-137.

Aliyu, O. M. and L. A. Hammed (2008): Nigerian cashew economy: a review of the nut production sector. Peerreviewed Proceedings of the $9^{\text {th }}$ Annual conference of International Academy of African Business and Development, The University of Florida, Gainesville, Florida, USA May 20-24, 2008. Edited By: Simon Sigué Athabasca University, Canada. 109-118. http://www. iaabd.org/pdf/2008_IAABD_Proceedings.pdf

Aliyu, O. M., O. O. AdeigBe and O. O. LAWAL (2014): Phenotypic stability analysis of yield components in cashew (Anacardium occidentale L.) using additive main effect and multiplicative interaction (AMMI) and GGE biplot analyses. Plant Breeding and Biotechnology, 2 (4): 354-369.

Arumuganathan, K. and E. D. EARLE (1991): Nuclear DNA content of some important plant species. Plant Molecular Biology Reporter 9 (3): 208-219.

Bennett, M. D. and I. J. Leitch (2011): Nuclear DNA amounts in angiosperms: targets, trends and tomorrow. Annals of Botany, 107: 467-590.

Bennett, M. D. and I. J. Leitch (2012): Plant DNA C-values Database. http://data.kew.org/cvalues

Bennett, M. D., I. J. Leitch, H. J. PRICE and J. S. JohnSTON (2003): Comparison with Caenorhabditis ( 100 $\mathrm{Mb})$ and Drosophila ( 175 Mb) using flow cytometry show genome size in Arabidopsis to be $\sim 157 \mathrm{Mb}$ and thus $\sim 25 \%$ larger than the Arabidopsis Genome Initiative estimate of $\sim 125 \mathrm{Mb}$. Annals of Botany, 91: $1-11$.

Bennetzen, J. L. and E. A. KellogG (1997): Do plants have a one-way ticket to genomic obesity? The Plant Cell, 9: 1509-1514.

Bennetzen, J. L., J. MA and K. M. Devos (2005): Mechanisms of recent genome size variation in flowering plants. Annals of Botany, 95: 127-132.

Beaulieu, J. M., A. T. Moles, I. J. Leitch, M. D. Bennett, J. B. Dickie and C. A. KNight (2007): Correlated evolution of genome size and seed mass. New Phytologist, 173 (2): 422-437.

Bhaskara-RaO, E. V. V. and K. R. M. Swamy (2005): Cashew. In: Chopra, V. L., Peter, K. V. (ed) Handbook of Industrial Crops. Food Products Press \& The Haworth Reference Press, Binghamton, New York. Pp. 77-136.

CAvalier-Smith, T. (2005): Economy, speed and size matter: evolutionary forces driving nuclear genome miniaturation and expansion. Annals of Botany 95: 147-175

Chen, S., C. H. Cannon, C. Kua, J. Liu and D. W. GaLBRAITH (2014): Genome size variation in Fagaceae and its implications for trees. Tree Genetics \& genomes 10: 977-988.

Chevalier C., M. Nafati, E. Mathieu-Rivet, M. Bourdon, N. Frangne, C. Cheniclet, J. Renaudin, F. Gevaudant and M. Hermould (2011): Elucidating the functional role of endoreduplication in tomato fruit development. Annals of Botany, 107 (7): 1159-1169. 
Chung, J., J. H. Lee, K. Arumuganathan, G. L. Graef and J. E. SPECHT (1998): Relationships between nuclear DNA content and seed size and leaf size in soybean. Theoretical and Applied Genetics, 96: 1064-1068.

Deckers, J., E. Cundall, S. H. Shomari, A. Ngatunga and G. BASSI (2001): Nut crops. Raemaekers, R. H. In: Crop Production in Tropical Africa. pp. 691-715.

DoležEl, J., S. SGORBATI and S. LuCRETTI (1992): Comparison of three DNA fluorochromes for flow cytometric estimation of nuclear DNA content in plants. Physiol. Plant. 85: 625-631.

DoležEl, J., J. Greilhuber, S. LuCRETti, A. Meister, M. A. LysÁK, L. NARdi and R. Obermayer (1998): Plant genome size estimation by flow cytometry: Inter-laboratory comparison. Annals of Botany, 82 (Suppl. A): 17-26.

DoležEl, J., J. Bartoš, H. Voglmayr and J. Greilhuber (2003): Nuclear DNA content and genome size of trout and human. Cytometry, 51A: 127-128.

DOLEŽEL, J. and J. BARTOS̆ (2005): Plant DNA flow cytometry and estimation of nuclear genome size. Annals of Botany, 95: 99-110.

Doležel, J., J. Greilhuber and J. SudA (2007): Flow cytometry with plants: An overview. In: DoLEŽEL, J., Greilhuber, J., SuDA, J. (ed) Flow Cytometry with Plant Cells. Analysis of Genes, Chromosomes and Genomes. Weinheim: Wiley-VCH; 2007. pp 41-65.

Duval, M., F. J. Bunel, C. Sitbon and A. M. Risterucci (2005): Development of microsatellite markers for mango (Mangifera indica L.). Molecular Ecology Notes, 5, 823-826.

Galbraith, D. W., K. R. Harkins, J. M. Maddox, N. M. Ayres, D. P. Sharma and E. Feroozabady (1983): Rapid flow cytometric analysis of the cell cycle in intact plant tissues. Science, 220: 1049-1051.

Galbraith, D. W., K. R. HARKIns and S. KNAPP (1991): Systemic endopolyploidy in Arabidopsis thaliana. Plant Physiology, 96: 985-989.

GREGORY, T. R. (2005): The C-value enigma in plants and animals: a review of parallels and an appeal for partnership. Annals of Botany, 95: 133-146.

GREILHUBER, J. (1998): Intraspecific variation in genome size: a critical reassessment. Annals of Botany, 82 (Suppl. A): 27-35.

GREILHUBER, J. (2005): Intraspecific variation in genome size in angiosperms: identifying its existence. Annals of Botany, 95: 91-98.

HAmmed, L. A. and E. A. AdEYemi (2005): Effects of nutsowing orientation and cotyledon removal on germination of cashew nuts and performance of the seedlings in the nursery. Nigerian Journal of Horticulture Science. Vol. 10: 59-64.

Hammed, L. A., O. M. Aliyu, K. E. Dada and S. Egbewale (2014): Cultivar type and nut sowing orientation influence germination and plant vigour in cashew (Anacardium occidentale L.). International Journal of Fruit Science, 14: 69-80.

Horjales, M., N. Redondo, A. Blanco and M. A. RODRÍGUEz (2003): Cantidades de DNA nuclear en Ãirboles y arbustos. Nova Acta Cientifica Compostelana (Bioloxía) 13: 23-33.

Johnston, J. S., M. D. Bennett, A. L. Rayburn, D. W. GAlBRAith and H. J. PRICE (1999): Reference standards for determination of DNA content of plant nuclei. American Journal of Botany 86: 609-613.

Knight, C. A., R. B. Clancy, L. Gotzenberger, L. Dann, and J. M. BEAULIEU (2010): On the relationship between pollen size and genome size. Journal of Botany, ID612017, 7 pages.dio: 10.1155/201/612017

Lietch, I. J. and M. D. BennetT (2004): Genome downsizing in polyploid plants. Biological Journal of the Linnean Society 82: 651-663.

LeITCH, A. R. and I. J. LEITCH (2008): Genomic plasticity and the diversity of polyploid plants. Science, 320: $481-483$.

Loureiro, J., E. Rodriguez, J. Doležel and C. SANtos (2006): Flow cytometric and microscopic analysis of the effect of tannic acid on plant nuclei and estimation of DNA content. Annals of Botany, 98: 515-527.

Manchester, S. R., V. Wilde and M. E. Collinson (2007): Fossil Cashew Nuts from the Eocene of Europe: Biogeographic links between Africa and South America. International Journal of Plant Science, 168 (8): 1199-1206.

Martin, P. J., C. P. Topper, R. A. Bashiru, F. Boma, D. De Wall, H. C. Harries, L. J. Kasuga, N. Katanila, L. P. Kikoka, R. Lamboll, A. C. Maddison, A. E. Majule, P. A. Masawe, K. J. Millanzi, N. Q. Nathaniels, S. H. Shomari, M. E. SiJaona and T. Stathers (1997): Cashew nut production in Tanzania: constraints and progress through integrated crop management. Crop Protection, 16: $5-14$

Mitchell, J. D. and S. A. MoRI (1987): The cashew and its relatives (Anacardium, Anacardiaceae). Memoirs of New York Botanical Gardens English 42: 1-76.

MuKHERJEE, S. K. (1950): Mango: its allopolyploid nature. Nature 166, 196-197.

Noirot, M., V. Poncet, P. Barre, P. Hamon, S. HAmon and A. De Kochкo (2003): Genome size variation in diploid African Coffea Species. Annals of Botany, 92: 709-714.

OHRI, D., A. BhARGAVA and A. ChATTERJEe (2004): Nuclear DNA amounts in 112 species of tropical hardwoods New estimates. Plant Biology, 6: 555-561.

ParamshivapPa, R., P. Phani-Kumar, P. J. Vithayathil and A. SRINIVASA-RAO (2001): Novel method for isolation of major phenolic components from cashew (Anacardium occidentale L.) nut shell liquid. J. Agric. Food Chem., 49, 2548-2551.

PeLL, S. K. (2004): Molecular Systematics of the Cashew family (Anacardiaceae). Ph.D Dissertation in the Department of Biological Sciences, Louisiana State University of Agricultural and Mechanical College, USA. pp207. http://anacardium.info/IMG/pdf/Caracterisationgenetique.pdf webpage visited $10^{\text {th }}$ November, 2014 .

RICKSON, F. R. and M. M. RICKSON (1998): The cashew nut, Anacardium occidentale (Anacardiaceae), and its perennial association with ants: extra-floral nectary location and the potential for ant defense. American Journal of Botany, 85 (6): 835-849.

Schmuths, H., A. Meister, R. Horres and K. BachmanN (2004): Genome Size Variation among Accessions of Arabidopsis thaliana. Annals of Botany, 93: 317-321.

Schnell, R. J., J. S. Brown, C. T. Olano, A. W. Meerow, R. J. CAMPBELL and D. N. KuHN (2006): Mango genetic diversity analysis and pedigree inferences for Florida cultivars using microsatellite markers. Journal of the American Society for Horticultural Science, 131: 214-224.

Siljak-Yakovlev, S., F. Pustahija, E. M. Åolic, F. Bogunic, E. Muratovic, N. BaÅIIC, O. Catrice and S. C. BRown (2010): Towards a genome size and chromosome number database of Balkan flora: C-values in 343 taxa with novel values for 242. Advanced Science Letter, 3: 190-213. 